\title{
Types and Motives of Corporate Social Responsibility and Environmental Reporting in Libyan Companies
}

\author{
Naser Benomran (Corresponding author) \\ School of Maritime Business and Management \\ University Malaysia Terengganu (UMT) \\ E-mail: naser19640@yahoo.com \\ Mohd Hassan Che Haat \\ School of Maritime Business and Management \\ University Malaysia Terengganu (UMT) \\ E-mail: hassan@umt.edu.my \\ Hafiza Binti Hashim \\ School of Maritime Business and Management \\ University Malaysia Terengganu (UMT) \\ E-mail: hafizaaishah@umt.edu.my \\ Nor Raihan Binti Mohamad \\ School of Maritime Business and Management \\ University Malaysia Terengganu (UMT) \\ E-mail: raihan@umt.edu.my
}

Received: 06-01- 2015

doi:10.7575/aiac.ijfas.v.3n.1p.1
Accepted: 25-03- 2015

Published: 30-04- 2015

\begin{abstract}
This study examined the types and the motives of Corporate Social Responsibility and Environmental Reporting (CSER) in Libya, a developing country, which has undergone many economic, political and social changes over a short period of time. An influential factor that regulates Libyan society is Islam. Drawing from the assumption that Islamic values in business include the fair treatment of employees, fair prices, honesty, and customer service respect for environment, charitable donations, and complete disclosures, the current study aims to investigate if types and motives of CSER have been influenced by the Islamic environment in which they operate. Both quantitative and qualitative methods were employed to collect data relating to CSER in Libyan firms. The quantitative study involved analysing the contents of 162 annual company reports produced between 2006 and 2012, while the qualitative study examined the perceptions of public relations managers and financial managers, which using interviews. Results from the quantitative study revealed that annual reports issued by Libyan companies actually give social and environmental disclosure, even if it is smaller than it was expected on the basses of the Islamic background of people operating in Libyan companies. In particular, that disclosure of environmental and employee information was higher than the disclosure of community, customers and product information. The qualitative results also revealed that Islam was a significant factor in increasing CSER disclosure. In addition, the managers believed that other motives such as government ownership and company characteristics influence CSER by companies. Both quantitative and qualitative results indicated that environmental, employee and customer information features were prominent in the annual reports of Libyan companies.
\end{abstract}

Keywords: Corporate Social Responsibility, Environmental Reporting, Corporate Social Responsibility and Environmental Reporting, Libya, Islam

\section{Introduction}

Libya, a key producer of high quality and low sulphur crude oil and gas, is strategically well-placed to take advantage of European markets. The emerging economy of Libya has experienced change over the last ten years (Mateos, 2005) and witnessed different political and economic systems (Wallace \& Wilkinson, 2004). An influential factor that regulates Libyan society is Islam (Bayoud, 2012). According to Ali (1996), Islam, the dominant religion in Libya, may have an influence on firms' disclosures. Since 2000, Corporate Social Responsibility and Environmental Reporting (CSER) has increasingly been practised in Libya, compared to previous years (Pratten \& Mashat, 2009) due to the pressure from stakeholders, suggesting the growing importance of CSER in Libyan firms. Interest in CSER may further develop the concept and practice of CSER (Bayoud, 2012).

The practice of CSER has passed through different stages. During the first stage, between 1970 and 1980 , most companies disclosed information about products and employees (Bayoud, 2012) as firms were not interested in environmental activities then. During the second stage, between 1980 and 1990, companies emphasized both social and 
environmental issues, and environmental disclosure involved in reducing environmental damage. During the third stage, starting from 1991 to the present day, firms have concentrated on environmental issues (Bayoud, 2012).

The present study evidences of CSER using both quantitative and qualitative analysis. The contents of 162 annual reports of Libyan companies were analysed and 24 public relations managers and 7 financial managers from 31 Libyan companies were interviewed to elicit information on the types and the motives of CSER in Libya. Content analysis of the annual reports and qualitative analyses of the contents of the interviews have extended available knowledge on the types and the motives of disclosure of CSER activities in Libyan organisations.

Although previous studies attempted to find out more about the types and motives of CSER in Libyan organisations, researchers relied on only quantitative data. The present study employs both quantitative and qualitative approaches to data collection and analysis to obtain deeper insights into CSER practices in Libya, focusing mainly on the types and the motives of CSER.

The paper proceeds as follows: Section 2 reviews accounting literature on CSER. Section 3 describes the Libyan context and discusses CSER in Libyan companies. Section 4 describes the methodology. Section 5 tabulates and presents the findings. The final Section6 summarises and discusses the findings in light of the literature reviewed.

\section{Literature Review}

In the last three decades, efforts have been made to enhance social and environmental responsibility of companies, due to the growing awareness of the financial costs of environmental and social effects (Gray, Owen \& Adam, 1996). Gray and Bebbington (2001) noted that Corporate Social Responsibility (CSR) has received more attention, as can be seen from the growing number of academic studies and interests in CSR shown by governments, accounting bodies, association bodies, factories, and business enterprises. CSR represents a type of corporate social receptiveness by the directors of companies and the managers to positively impact the social environment.

Different definitions of CSR have been formulated the literature. According to Radebauh and Gray (2002, p. 119), CSR refers to "accountability to society as a whole with respect to matters of public interest such as community welfare, public safety, and the environment." CSR deals with the social and environmental aspects in business (Imran, Rehman, Yilmaz, Nazir, \& Ali, 2010). It is now apparent that CSR disclosure provides information on a company's interaction with its stakeholders, community participation-related disclosure, product and consumer relations (Deegan, 2002; Epstein \& Freedman, 1994; Gray, Kouhy \& Lavers, 1995; Hackston \& Milne, 1996; Ng, 1985; Williams, 1999). The main essence of these definitions is similar in that the associations are undertaking CSR activities for creating healthy products, raising awareness for a better environment, enhancing social consciousness of most important issues, taking care of employees and engaging in philanthropic activities to reach sustainability in the business markets (Imran et al., 2010). According to Pratten and Mashat (2009) companies, in making a profit, must show that they are behaving in a moral fashion and taking responsibility for their actions toward a society.

Therefore, the firms need to present social information related to their activities in the workplace, the community, the environment and the consumer and their actions should be acceptable to all stakeholders. CSR reporting and 'transparency initiatives' play key roles in impacting the media and public opinion because they help to portray companies as responsible citizens that care about people and the environment more than profits (Frynas, 2010). Thus, CSR may be regarded as "the provision of financial and non-financial information relating to an organization's interaction with its physical and social environment" (Guthrie \& Mathews, 1985 as cited in Pratten \& Mashat 2009, p. 312). Environmental and social accounting disclosures appeared to reflect public social priorities, respond to government pressure, accommodate environmental pressures and sectional interests and protect corporate prerogatives and projected corporate images (Guthrie \& Parker, 1989).

Moreover, a company's annual reports and social disclosures can help reduce the effects of certain activities that are supposed to adversely affect the image of such company (Deegan, Rankin, \& Voght, 2000). The Environmental Reporting (ER) may be used to enhance the community's perception to environmental issues, or divert attention from adverse environmental situations (Deegan \& Rankin, 1996; Patten, 1992). ER aims to decrease the environmental costs that can face by companies, which especially applies to polluting companies (Romlah, Takiah, \& Nordin, 2002). Therefore, the annual report is the most important source of environmental information due to its legal compliance (Deegan \& Rankin, 1996; Hughes, Anderson \& Golden 2001; Tilt, 1994), and its important role of reporting to stakeholders the measures taken to manage environmental issues (Crowther, 2002). CSR also refers to the duty of companies in taking into account their employees and their welfare through relevant programs (Manakkalathil \& Rudolf, 1995; Oppewal, Alexander, \& Sullivan, 2006).

The disclosure provided in the annual report therefore forms a part of the corporate social responsiveness within the economic activity (Mangos \& Lewis, 1995). In addition, Elasrag (2011) points out that global CSR is a global initiative of the United Nations (UN), it was released in 1999. The nature of CSR suggested by such initiative is divided into four groups, which cover human rights, standards of work, preservation of the environment and anti-corruption. However, it has been observed that not all CSR provides comprehensive information, despite pressures from stakeholders groups and community. McWilliams and Siegel (2000) and Castka, Bamber, Bamber and Sharp (2004) note that directors' unwillingness to disclose CSR information stem from the need to achieve a balance between the requirement for optimizing earning from disclosing CSR information and the need to meet the request for information from multiple stakeholders. In recent years, environmental litigations have pushed companies to enter into environmental responsibility including environmental disclosure and reporting matters, as argued by Margolis \& Walsh (2003). 
However, many companies are not realizing the significance of CSR and are still not investing in this area. The media, in particular the print media, do often not discuss the importance of CSR. Very few printed articles have been issued in magazines and newspapers about employee rights, environmental problems, CSER best practices, and company disclosure on CSER. Many firms address environmental issues as part of their CSR initiatives because ER practices are part of CSR (Imran et al., 2010). However, very few prior studies on the ER in developing countries have been reported to date, possibly due to the lack of mandatory CSR and environmental reporting standards (Buniamin, Alrazi, Johari, \& Abd Rahman, 2008).

Extant literature state that the level and quality of corporate disclosure and of CSER in particular were influenced by a number of environmental factors (Mathews, 1993a; Tsang, 1998) such as political, legal factors, social, economic and cultural factors which play a significant role in identifying amount of corporate disclosure (Lewis, 2001). The disclosure of CSER information can improve the image of companies within the society by driving them to fulfil their social responsibility (Zahra \& Stanton, 1988). In addition, the increase in pressure from various groups represents the primary driver for CSER. These pressures come from concerned parties about the social and environment issues and improving CSER. For example, O'Rourke (2004) clarified that the main demand is for the public to know about the company's activities and concerns about environmental and social influence on community. The country must also issue laws and legislation that related to environment.

Interestingly, a recent study on the Libyan society found that one of the most significant drivers behind the increase in CSER activities is Islam (Bayoud, 2012), which is also the main factor that impacts the behaviour of Libyan society (Pratten \& Mashat, 2009). According to Ali (1996), family social life is organized according to the Islamic traditions in Libya, and Islam may have an influence on firms in terms of their disclosures. For such reasons, the Libyan context appears to be an interesting case for studying social factors that impact on CSER disclosure.

\section{Libyan Context}

\subsection{Social and religious context and CSER requirements}

This section presents an overview of the Libyan situation from the religious, cultural, social and legal perspectives, all of which are believed to affect the CSER disclosure (Mathews, 1993a; Mathews, 1997b; Tsang, 1998; Haniffa \& Cooke, 2002). Influences on accounting and CSER in particular are included. Some concerns about CSER practices and disclosures in Libyan companies are also addressed.

Since the new century, a series of economic, social and legal reforms have been gradually introduced in Libya. In 2004, Libya applied to join the World Trade Organization (WTO), a move that mandated the review of laws to meet WTO requirements (Larbsh, 2010). However, these laws were not effectively enforced. Libyan companies are obliged to comply with specific laws. One of these laws relate to social welfare, health, safety and training. Another relates to the environment. Law No. 13 of 1984 specifies that companies must collect, transport, and dispose of wastes (Bayoud, 2012). Libyan Tax Law encourages companies operating in Libya to participate in social activities. For example, the law grants a tax privilege for donations to officially recognized charity institutions (Mashat, Ritchie, Lovatt, \& Pratten, 2005). The Libyan Environmental Protection Law No. 13 of 2003 as well as the Industrial Security and Employees Health and Safety Law of 1976 have identified several key points of corporate environmental disclosure, including environmental protection, environmental harm, health and safety of employees, security of employees, evidence (monetary, quantitative, and qualitative analysis), and types of disclosure (poor, neutral, and excellent) (Ahmad, 2004).

Although Libya established the Public Organization of Environment (POE) in 2000 to protect the environment, the environmental disclosure provided by Libyan companies has been scarce, compared to the environmental disclosure provided by companies in more developed countries. In addition, the establishment of the Libyan Stock Market (LSM) and the Libyan environmental law no. 15 of 2003 may push ER in Libya. The requirement of the laws is to reduce the negative effects on the environment and encourage Libyan companies to protect the environment and disclose it. However, Mashat et al. (2005) found that environmental disclosure had not been properly published in the annual reports of Libyan companies, and that the level of ER in Libya is still low and generally the available information lacked uniformity and had very little disclosure value. In the present day context, companies registered in the LSM are expected to provide more specific information to give all investors in the market the right picture about themselves and to attract more investment (Elmogla, 2009).

According to Mashat et al. (2005), government-owned companies do not disclose the requested bad news to enhance the corporate image, or their reputation or to avoid social pressure. The study of Elmogla (2009) showed that Libyan companies generally disclose some information related to social responsibility, possibly in response to incentives given by the authorities. According to Pratten and Mashat (2009), more laws are needed to advance the extent of CSER as currently the quantity and quality information related to CSER is still very limited. Moreover, when available, the disclosures often adopted the narrative format, but not in the quantitative form, similarly to what has been found by studies conducted with reference to non-Islamic countries (e.g. Farneti \& Siboni, 2011). Most reports in Libyan companies included the information on employees and some community disclosure (Pratten \& Mashat 2009). Ahmad and Gao (2004) have examined the corporate ER in Libyan companies and revealed that no confirmation of the existence of environmental reporting in the country. However, they found that around $70 \%$ of their sample firms have disclosed information about their employees such as the health and safety. By studying the years 1998 to 2001, Ahmad (2004) found only the health and safety category disclosed in annual reports in Libyan companies but no other CSER categories. 
A literature review has drawn attention to the scarcity of studies that examined the value of CSR in developing countries (Muthuri, Moon, \& Idemudia, 2012). Although the extent of CSER has risen in Libya since 2007 due to pressures from stakeholders (Pratten \& Mashat, 2009), information on CSER activities remains still scarce in the annual reports of Libyan companies. The dearth of knowledge could be attributed to the fact that the disclosure of such activities is voluntary and that most firms in Libya fail to understand the importance of CSER disclosure in their annual reports and are unaware of the influence of CSER disclosure (Pratten \& Mashat, 2009). However, although the Libyan government has issued a number of laws to regulate the behavior of business organizations towards the environment, these regulations are rarely enforced.

Within the Arab world, in which Libya constitutes an important part, empirical studies on CSER practices are still lacking (Abu-Baker \& Naser, 2000; Al-Khater \& Naser, 2003; Jahamani, 2003). Therefore, information on CSER practices in Libya, in particular, remains scarce. Libyan disclosure requirements are low. The reasons for this are the lack of legal requirements and administrative difficulties (Mashat et al., 2005). According to Bayoud (2012), religion plays a significant role in Libyan society. Islam and Arabic cultures form the backbone of the country's culture. Arabic language, the extended family and tribal values are therefore important characteristics that have shaped the social fabric of the Libyan society (Agnaia, 1996). It has been pointed out that in Arabic countries, religion, culture, society, and politics exert a vital influence on individuals' behavior particularly in Libya (Hamid, Craig \& Clarke, 1993; Aghila, 2000). Islam came to Libya in AD 642, and now all Libyans are Sunni Muslims. Beekun and Badawi (2005, p. 143) stressed that "Islam is a way of life, not just a religion. As a result, business ethics cannot be separated from ethics in the other aspects of a Muslim's daily life".

The objective of this research is to provide the much-needed knowledge on the types and the motives of CSER in Libyan companies and the motives that impact the practice of CSER in Libya.

\section{CSER Reporting Guidelines}

The present study used the categories and subcategories of the Egyptian index for the Environment, Social, and Governance (ESG), which are related to CSER categories as this is the first developed index in the Arabic world (S\&P/EGX ESG Index, 2010). The Ministry of Investment in Egypt developed the ESG index to encourage firms to be more transparent and to disclose their social, environmental, and governance practices more clearly to increase their competitive advantage. The index was developed by a consortium of Standard \& Poor's (S\&P) and others that categorized CSER activities into four categories (environment, employee information, community investment, and customer and product). These categories are brifly presented as follows:

The Employee disclosure includes information about the influence of organizational activities on employees (Bayoud, 2012). According to Egyptian Index for CSER elements such disclosures covers the following items:

a. Employee Relations/Job Creation

b. Labour Rights

c. Equal Opportunity

\section{d. Union Relations}

The Community Investment disclosure refers to any disclosures of information related to community involvement (Van der, Adhikari \& Tondkar, 2005). The Egyptian Index for CSR provides the following items:

a. Human Rights

b. Community Investment

The Customers/Products disclosure encompasses the following items (S\&P/EGX ESG Index, 2010):

a. Product Safely

b. Anti-trust

c. Costumer Outreach and Product Quality

The Environmental disclosure is used to provide information about the impacts of company on the physical environment. The environmental disclosures encompass the following types of items (S\&P/EGX ESG Index, 2010):

a. Environmental Pollution

b. Natural Resources Use

c. Management Policy and performance Indicators

\section{The Research Methods}

The current work employed both quantitative and qualitative approaches. The quantitative approach examined the annual reports of companies produced between 2006 and 2012 (see Table 1) to determine the types and motives of CSER in Libyan companies, using content analysis as a systematic method of categorizing and analyzing the content of texts. The annual reports of 2006-2012 periods from Libyan companies were chosen for this study, because these reports were the latest years that were available, when the authors have collected annual reports. Thus, 162 annual reports were obtained for a seven-year period from 42 firms across six different industries (banks, engineering, services, manufacturing, insurance and oil sectors). The authors have chosen to analyze these six sectors for the following reasons. First, these sectors have annual reports mandatory published. Second, these sectors are interested in CSER 
activities and they have been engaged in CSER activities as indicated by previous research (Ahmad, 2004; Pratten \& Mashat, 2009; Bayoud, 2012). Third, they were chosen because the annual reports were relatively easy to obtain for the researchers. However, it has to be noticed that it was not possible to analyze the entire period (2006-2012) for all the 42 companies of the sample, because some companies lost their annual reports as a result of the war and revolution of 2011.

Table 1. Summary of Sectors, Companies and Annual Reports

\begin{tabular}{lcccc}
\hline Sectors & Companies & Percentage & $\begin{array}{c}\text { Annual Reports } \\
\text { Collected }\end{array}$ & Percentage \\
\hline Manufacture & 12 & $29 \%$ & 20 & $13 \%$ \\
Services & 1 & $2 \%$ & 5 & $3 \%$ \\
Engineering & 2 & $4 \%$ & 2 & $1 \%$ \\
Insurance & 4 & $10 \%$ & 15 & $9 \%$ \\
Oil & 12 & $29 \%$ & 73 & $45 \%$ \\
Banks & 11 & $26 \%$ & 47 & $100 \%$ \\
Total & 42 & $100 \%$ & 162 & \\
\hline
\end{tabular}

This study employed content analysis as a primary method of research. Content analysis is a systematic method of categorizing and analysing the content of texts. This method analysed the CSER of each category using the number of sentences and a "yes/no" or $(1,0)$ scoring methodology. The subcategories were given a score of 1 if information was given, whereas a score of 0 was given if no information was disclosed .The aggregate score for each company was determined by adding scores of 1 (Al-Tuwaijri, Christensen \& Hughes,2004).

Further, face-to-face interviews were performed to elicit information on important related issues and to collect insight into the reasons for CSER (Walker, 1985; Judd, Smith, \& Kidder, 1991). The design of an interview guide came from the literature review presented in Sections 1 and 2 .The interviews, with public relations managers and financial managers of the companies were conducted between March 2013 and June 2013. In total, 31 interviewees from 31 companies of different sectors were collected. 7 participants (23\%) were financial managers and 24 (77\%) participants were public relations managers (see Table 2). Public relations and financial managers were chosen for interviewed because they were assumed to have formulated opinions on CSER while preparing annual reports. Each interview lasted between 60 minutes to 90 minutes, and recorded in notebooks and tape recorders. Each interview lasted between 60 minutes and 90 minutes. They were recorded and transcribed for reporting and discussing purposes.

Table 2. Sample Profiles of Interviewees

\begin{tabular}{lcccc}
\hline Sector Name & $\begin{array}{c}\text { Financial } \\
\text { Managers }\end{array}$ & $\begin{array}{c}\text { Public Relations } \\
\text { Managers }\end{array}$ & \multicolumn{2}{c}{$\begin{array}{l}\text { Total } \\
\text { and percent }\end{array}$} \\
\hline Manufacturing & 2 & 7 & 9 & $(29 \%)$ \\
Services & 1 & 0 & 1 & $(3 \%)$ \\
Banks & 1 & 10 & 11 & $(36 \%)$ \\
Insurance & 1 & 2 & 3 & $(10 \%)$ \\
Engineering & 1 & 0 & 1 & $(3 \%)$ \\
Oil & 1 & 5 & 6 & $(19 \%)$ \\
Total & 7 & 24 & 31 & $(100 \%)$ \\
Participation rate & $23 \%$ & $77 \%$ & $100 \%$ & \\
& & & & \\
\end{tabular}

\section{Results}

Table 3 shows that the disclosure of environmental and employee information was high as compared with community, customers and product information. The environmental categories were divided into three subcategories, namely environmental pollution (29.01\%), natural resource use (16.04\%), and management policy and performance indicators (7.4\%). The employee categories were divided into four subcategories: union relations $(86 \%)$, labour rights $(75 \%)$, equal opportunity (30.42\%) and employee relations and job creation (8.02\%), resulting in a high visibility obtained for employee information. The community categories were divided into two subcategories: human rights $(22.22 \%)$ and community investment $(5.55 \%)$. The customer and product categories were divided into four subcategories: product safety $(38 \%)$, customer outreach $(3.08 \%)$, product quality $(2.5 \%)$, and antitrust $(1.2 \%)$ The disclosure of employee information constituted a significant part of the CSER made by companies in these sectors and ranked as the most disclosed information category, while customer and community information ranked as the least disclosed information category in these sectors. These results are compatible with those reported by Mashat (2005), Elmogla (2009), and 
Bayoud (2012) concerning CSER disclosure in Libyan contexts, which show employee and environment information disclosed represented a significant part of the CSER in Libyan companies.

Table 3. CSER by Categories Disclosed in Sectors Areas Disclosed by Libyan Companies

\begin{tabular}{lcc}
\hline Categories and subcategories of CSER disclosure & \multicolumn{2}{c}{ Annual Reports } \\
& No & $\%$ \\
\hline Environmental disclosure: & 47 & 29.01 \\
Environmental Pollution & 26 & 16.04 \\
Natural Resource Use & 12 & 7.4 \\
Management Policy and Performance Indicators & & \\
Employee Information: & 12 & 8.02 \\
Employee Relations/Job Creation & 121 & 75 \\
Labour Rights & 49 & 30.42 \\
Equal Opportunity & 139 & 86 \\
Union Relations & & \\
Community: & 36 & 22.22 \\
Human Rights & 9 & 5.55 \\
Community Investment & & \\
Customers/Product: & 61 & 38 \\
Product Safety & 4 & 2.5 \\
Product Quality & 2 & 1.2 \\
Anti Trust & 5 & 3.08 \\
Customer Outreach & &
\end{tabular}

Table 4 shows the differences between the six sectors in CSER: manufacturing, banks, insurance, services, engineering, and oil companies by using the number of sentences method. In particular, the results presented in Table 4 illustrate that the disclosure of employee information and environmental information was higher as compared with customers/products disclosure and community disclosure, which was lower in these sectors. The employee ranked as the most disclosed information category and information disclosed formed a significant part of the CSER made by Libyan firms in the manufacturing, banks, insurance, services, engineering and oil sectors, environment information and community information, whereas customers and products disclosure ranked as the least disclosed information category in these sectors. The findings of studies by Mashat et al. (2005), Elmogla (2009), and Bayoud (2012) are close to the results presented in Table 4 .

Table 4. CSER by Categories Disclosed in Sectors

\begin{tabular}{|c|c|c|c|c|c|c|c|c|}
\hline \multirow{2}{*}{$\begin{array}{l}\text { Categories of } \\
\text { CSER }\end{array}$} & \multirow{2}{*}{$\begin{array}{l}\text { Annual Reports } \\
\text { (number and } \\
\text { percentage) }\end{array}$} & \multicolumn{7}{|c|}{ Sector } \\
\hline & & Manufacturing & Banks & Insurances & Engineering & Services & Oil & Total \\
\hline Environmental & No & 14 & 9 & 0 & 0 & 2 & 66 & 91 \\
\hline disclosure & $\%$ & 70 & 19 & 0 & 0 & 40 & 90 & $56 \%$ \\
\hline Employee & No & 19 & 18 & 11 & 1 & 4 & 70 & 123 \\
\hline disclosure & $\%$ & 95 & 90 & 73 & 50 & 80 & 96 & $76 \%$ \\
\hline Community & No & 11 & 18 & 0 & 0 & 0 & 49 & 78 \\
\hline disclosure & $\%$ & 55 & 38 & 0 & 0 & 0 & 67 & $48 \%$ \\
\hline Customers/ & No & 17 & 30 & 9 & 2 & 3 & 0 & 61 \\
\hline /Products & $\%$ & 85 & 64 & 60 & 100 & 60 & 0 & $38 \%$ \\
\hline Total annual & No & 20 & 47 & 15 & 2 & 5 & 73 & 162 \\
\hline reports & $\%$ & $12 \%$ & $29 \%$ & $9 \%$ & $2 \%$ & $3 \%$ & $45 \%$ & $100 \%$ \\
\hline
\end{tabular}

The Levene's test and the t-test for equality of variances and means were used for the results. These tests show the differences found between categories of CSER disclosure in annual reports by type of industry. The levels of environmental disclosure found significant differences in this test. For instance, environmental disclosure had a $p$-value 
of 0.042 and $\mathrm{p}$-value of 0.001 respectively. However, no significant differences were found in levels of employee disclosure, community disclosure and consumer disclosure (see Table 5).

Table 5. Levene's Test and T-Test for CSER in Annual Reports

\begin{tabular}{|c|c|c|c|c|c|}
\hline \multirow[t]{2}{*}{ Categories of CSER } & \multicolumn{3}{|c|}{ Levene's Test for Equality of Variances } & \multicolumn{2}{|c|}{ t-test for Equality of Means } \\
\hline & $\mathrm{F}$ & Sig (2-tailed) & $\mathrm{t}$ & Sig. (2-tailed) & Mean Difference \\
\hline Environmental Disclosure & 4.436 & 0.042 & $-3.745-$ & 0.001 & $0.281-$ \\
\hline Employee Disclosure & 0.519 & 0.476 & $-1.193-$ & 0.240 & $-.0470-$ \\
\hline Community Disclosure & 0.001 & 0.974 & $-1.690-$ & 0.099 & $-0.124-$ \\
\hline Customer Disclosure & 0.971 & 0.331 & 0.365 & 0.717 & 0.025 \\
\hline
\end{tabular}

\subsection{Insights into reasons for disclosure}

Most interviewees in the services, insurance and banks sectors considered customer and employee information more important than other CSER information in annual reports. Interviewees in the oil and manufacturing sectors, on the other hand, confirmed the importance of environmental, employee and customer information as compared with other CSER information. In addition, service firms in Libya were interested in employees and customers information. Furthermore, some interviewees believed that industrial companies took into account environmental impacts that may affect their community. Furthermore, most interviewees in the private sector considered that customer and employee information are more important in annual reports than other CSER categories. The interviewees also confirmed that customer information and environmental information in government owned companies were more important than other CSER categories. For instance, Libyan firms disclose information on expenditure on employees' health costs, training and safety costs, employee benefits, product safety, product quality, etc. One interviewee from a government-owned company mentioned that his company was subject to many problems in the previous period due to lack of interest in disclosing CSER activities, which led to lower company profitability. In addition, one of the financial managers stated that the companies listed in the stock market disclosed more details about CSER activities than others. Furthermore, five interviewees (16\%) did not know. When the Libyan government started to establish the stock market and privatize most government companies, Libyan companies tried to choose an appropriate accounting policy, which provides IASs and transparency, as illustrated in the following comment:

I think the requirements of the stock market, applying environmental laws, the growth of social and environmental awareness of the Libyan companies are the motives for disclosing CSER information in the annual reports.

Moreover, two financial managers believed that the policy of management regarding the importance of disclosing CSER information played an important role in increasing the extent of CSER information in their annual reports. The following comment reflects their attitudes:

The policy of senior management towards social disclosure significantly affects the quantity and quality of CSER disclosed in annual reports.

Table 6 shows the main factors impacting the extent of CSER. As can be seen, 18 interviewees (58\%) mentioned that the industry type had a significant effect on the extent of CSER disclosure in annual reports, as illustrated in the following comment:

I believe that type of industry of has a major influence on the extent of CSER disclosed, particularly with regard to industrial companies, which expose all kinds of CSER information.

Furthermore, the majority of managers stated that there was a difference between one industry and another in the extent of CSER information disclosed in annual reports, particularly with regard to industrial companies. 19 interviewees (61\%) revealed that the ownership of a company was one of the most important motivations to practice CSER, and the expansion of the ownership of a company was considered one of the most important motivations for CSER. In addition, 19 interviewees (61\%) believed that big firms disclosed more CSER information than small firms, and big companies were more aware of the importance of CSER than small firms. As one interviewer indicated:

I think that large companies have the highest level of CSER disclosure from realizing the importance of CSER activities to make them more attractive to investors and also to increase their reputation.

They think that the concern about CSER encourages shareholders' to force large companies to consider their environmental and social performance. Also, large companies provide more information about CSER activities to make them more attractive to investors. For example, large firms offer large amounts of information concerning their CSER 
activities to their stakeholders. Thus, company size had an important effect on the extent of CSER disclosure as illustrated in the following comments:

Not only does company affect CSER but it also affects the volume of information and this is due to the administration being convinced of the importance of disclosing this information in order to benefit from disclosure, to encourage investors and enhance their reputation.

Hence, the size of a company has an important bearing on the extent of CSER disclosure. 20 interviewees (65\%) said that the main factor was company age, as it would give a firm time to obtain expertise and competencies required for improving the preparation of all information. 25 of interviewed (81\%) stressed that religion is the most important factors which influence the extent of CSER. Most of the managers agreed that Islamic beliefs affected the increase of CSER disclosure, and they believed that Islamic beliefs motivated Muslims to devote more attention to the community and the environment, which in turn, led to better disclosure of CSER in the annual reports of companies. The following comment best expresses the interviewees' sentiments:

I think when a Muslim maintains the environment in which God created clean; this means that he or she wants to get closer to God Almighty.

Majority of managers believed that the application of labor laws, the effect of religion, level of culture, level of education and interests of stakeholders drive employees to do their work to the fullest. In addition, the Islamic religion is considered one of the most important factors behind the pressure for companies to undertake social activities and to disclose them. Therefore, Islam is the driver factor behind the increase of CSER activities in Libyan companies. According to Bayoud (2012) as most Libyans are religious, therefore the religion is one of the most important aspects of Libyan society. Islam has thus shaped the country's cultural background. The results of the current study support the idea that religion is one of the most important drivers behind the increase in CSER activities in Libya (Pratten \& Mashat 2009).

The results obtained from interviews support the quantitative findings of this study, and agree with findings of Mashat et al. (2005), Elmogla (2009), and Bayoud (2012). In summary, the interviewees confirmed the types of CSER disclosure in the Libyan firms revealed by content analysis, suggesting that the main reason for the disclosure of CSER information was the Islamic religion. They also reported that the importance of categories of CSER is perceived as different. Twenty-four of interviewees (77\%) believed that providing positive CSER disclosure in annual reports helped company to increase profitability and assisted managers in decisions-making. In summary, it was found that environmental, employee and customer information represent the most disclosure in annual reports of Libyan companies. The majority of interviewees considered CSER as one of the most important instruments, which could help the Libyan companies to enhance reputation and image, and improve financial performance. Table 6 shows main factors impacting the extent of CSER in Libyan companies mentioned by the interviewees.

Table 6. Main Factors Impacting the Extent of CSER

\begin{tabular}{lcc}
\hline Factors & Number of interviews & The percentage of interviews \\
\hline Religion & 25 out of 31 & $81 \%$ \\
Company age & 20 out of 31 & $65 \%$ \\
Company size & 19 out of 31 & $61 \%$ \\
Government Ownership & 19 out of 31 & $61 \%$ \\
Type of industry & 18 out of 31 & $58 \%$ \\
\hline
\end{tabular}

\section{Conclusion}

The purpose of this study was to determine the type and the motives of CSER in the annual reports of the Libyan companies in six industries (manufacturing, services, engineering, insurance, banking and mining sectors). This investigation was motivated by the emphasis of the relevant literature on the reasons for disclosing CSER information, as a primary motivation that can affect company performance and the building of a positive company image.

The current research found that Islamic beliefs, company characteristics, and government ownership factors were considered as the most main effective factors in CSER practices in Libyan companies. Islamic values in business include the fair treatment of employees, fair prices, honesty, and customer service respect for environment, charitable donations, and complete disclosures. The essential features of Islamic religion indicate that all people should be treated with respect, care for the community and the environment be responsible, observe good conduct and be fair. This study provided evidence from managers about the types and the motives of CSER in the company. Thus, the essential features of Islamic religion background imply high levels of disclosure, and therefore the low level of CSER disclosure found in Libyan companies is could be surprising. In addition, previous studies about CSER disclosure in Libya have shown low level compared with neighbors such as Egypt (Larbsh, 2010). Past research into CSER in Libya suggests that CSER practices are often unimportant (Bayoud, 2012). However, the present research showed that companies could reap major benefits from disclosing CSER information. Some of these benefits include attracting investment and consumers, 
in addition to enhancing the company image. The results also highlighted the types of CSER disclosed by Libyan companies. These include environmental disclosure, employee disclosure, community disclosure and customer disclosure. Employee information constituted a significant part of the CSER in Libyan companies. These findings help to obtain insight on the motives for disclosing CSER information in the annual reports, which include the need to fulfill the requirements of the stock market, observe environmental laws and increase the social and environmental awareness of the Libyan companies.

In any study, there are some limitations that should be followed when interpreting the findings. In particular, although many studies have examined the types and motives of CSER, there are few studies that examined this issue in Arabic countries. This study used annual reports as one of the important data sources in the Libyan companies (Bayoud, 2012). Unerman (2000) and Zeghal and Ahmed (1990) pointed out that only a small proportion of a total CSER might be reached exclusively through the annual reports. Hence, the data used do not fully reach CSER practices in Libyan companies. Moreover, content analysis plays a significant role in this research; however, there are some limitations in using content analysis. Tilt (1994) noted that content analysis is not sufficient due to fact that different analysts could obtain different results from the same document. Therefore, more research needs to be undertaken, utilizing a wider range of firms, to determine if CSER in Libya maintains its own identity.

This study contributes to the CSER literature that was considered to be limited in terms of detailed case studies in developing economies, especially in Arab and Islamic world. Theoretically, the study contributes by evaluating the CSER, which complements previous studies in developing countries. This study is important for several reasons. First, the study would contribute to the literature to help the researchers through the provision of the modern CSER practices in Libya. Second, the study incorporates the issue of CSER, which could be regarded as among the first attempts in Libya. Third, it would perhaps stimulate Libyan companies to be more social and environmentally responsible in the future, as well as to be more transparent and disclose governance, social and environmental practices to increase their competitive cultures. Fourth, for policy makers, this research would provide indispensable evidence on the necessity of revisiting the existing standards and regulations. For instance, Libya may need to reinstate the importance of social and environmental performance in companies, and introduce specific standards on social and environmental accounting.

It is expected that this study will bring the issue of CSER to the attention of the Libyan researchers for further research in this field. This study presents key insights into CSER in Libyan companies. It clarifies the benefit and importance of CSER in Libya. The key insights give a deeper understanding about CSER in the Libyan firms. This research can contribute not only to the Libyan context, but it also can be utilized to the wider field of CSER research. Hence, this research makes an important contribution to the literature in the area of CSER in emerging and developing countries. In addition, the results in this research encourage Libyan firms to improve their CSER practice and to increase transparency under Islamic religion.

This study only focuses on annual reports, using seven years of annual reports for Libyan companies. However, future research is expected to use reports over a longer period of time. In addition, because this study examined CSER before and through the Libyan revolution 2011, future research should examine these influences after the revolution and comparison of the extent of CSER between Libyan companies and counterparts foreign companies.

\section{References}

Abu-Baker, N. and Naser, K. (2000). Empirical evidence on corporate social disclosure practices in Jordan. International Journal of Commerce and Management, 10(3), pp. 18-34.

Aghila, E. (2000). Job Satisfaction and Work Commitment in the Context of Libya. Unpublished PhD Thesis, Manchester Metropolitan University, UK.

Agnaia, A. (1996). Assessment of management training needs and selection for training: the case of Libyan companies. Manchester, UK: MCB UP Ltd, 17.

Ahmad, N. (2004). Corporate Environmental Disclosure in Libya: Evidence and Environmental Determinism Theory. Unpublished PhD thesis, Napier University, Edinburgh.

Ahmad, N. and Gao, S. (2004). Changes, problems and challenges of accounting education in Libya, accounting education. Accounting Education: an international journal. Taylor \& Francis Online, 13(3), pp. 90-365. DOI:10.1080/0963928042000273825

Ali, A. (1996). Organisational development in the Arab World. Journal of Management Development, 15(5), pp. 4 - 21. Al-Khater, K. and Naser, K. (2003). Users' perceptions of corporate social responsibility and accountability evidence from an emerging economy. Managerial Auditing Journal, 18(6/7), pp. 538-548.

Al-Tuwaijri, S. Christensen, T. and Hughes, K. (2004). The relations among environmental disclosure, environmental performance, and economic performance: a simultaneous equations approach, Accounting, Organizations and Society Journal, 29(5-6), pp. 447-71.

Bayoud, N. (2012). Corporate Social Responsibility Disclosure and Organizational Performance: The Case of Libya, A Mixed Methods Study. Unpublished PhD Thesis, University of Southern Queensland. 
Beekun, I. and Badawi, A. (2005). Balancing ethical responsibility among multiple organizational stakeholders: the Islamic perspective. Journal of Business Ethics, 60, pp. 131-45.

Buniamin, S., Alrazi, B., Johari, N. and Abd Rahman, N. (2008). An investigation of the association between corporate governance and environmental reporting in Malaysia. Asian Journal of Business and Accounting., 1 (2), pp. 65-88.

Castka, P., Bamber, C., Bamber, D. and Sharp, J. (2004). Integrating corporate social responsibility (CSR) into ISO management systems - in search of a feasible CSR management system framework. The TQM Magazine, 16(3), pp. 216-224.

Crowther, D. (2002). A Social Critique of Corporate Reporting: A Semiotic Analysis of Corporate Financial and Environmental Reporting. Hampshire. Ashgate.

Deegan, C. (2002). Introduction the legitimising effect of social and environmental disclosure - a theoretical foundation. Accounting, Auditing amd Accountability Journal, 15(3), pp. 282-311.

Deegan, C. and Rankin, M. (1996). Do Australian companies report environmental news objectively? An analysis of environmental disclosures by firms prosecuted successfully by the EPA. Accounting, Auditing and Accountability Journal, 9(2), pp. 50-67.

Deegan, C., Rankin, M. and Voght, P. (2000). Firms' disclosure reactions to major social incidents: Australian evidence. Accounting Forum, 24(1), pp. $101-130$.

Elasrag, H. (2011). Corporate Social Responsibility: Challenges and Prospects for Development in Arab countries. Munich Personal RePEc Archive.

Elmogla, M. (2009). Corporate Social Reporting in a Transition Economy: The Case of Libya. Unpublished PhD Thesis, University of Huddersfield.

Epstein, M. and Freedman, M. (1994). Social disclosure and the individual investor. Accounting, Auditing and Accountability Journal,. 7(4), pp. 94-109.

Farneti F. and Siboni B. (2011). An analysis of the Italian governmental guidelines and of the local governments' practices for social reports, Sustainability Accounting, Management and Policy Journal, 2(1), pp. 101-125.

Frynas, J. (2010). Corporate social responsibility and societal governance: lessons from transparency in the oil and gas sector. Journal of Business Ethics, 93, pp. 163-179.

Gray, R. and Bebbington, J. (2001). Accounting for the Environment. Paul Chapman Publishing Ltd, Part II.

Gray, R., Kouhy, R. and Lavers, S. (1995). Corporate social and environmental reporting - A review of the literature and a longitudinal, study of UK disclosure. Accounting, Auditing and Accountability, 8( 2), pp. 47-77.

Gray, R. Owen, D. and Adam, C. (1996). Accounting and Accountability. London; Prentice Halls Inc.

Guthrie, J. and Mathews, M. (1985). Corporate social reporting in Australia. Research in Corporate Social Performance and Policy, 7, pp. 251-271.

Guthrie, J. and Parker, L. (1989). Corporate social reporting: a rebuttal of legitimacy theory. Accounting and Business Research, 19, pp. 343-352.

Hackston, D. and Milne, M. (1996). Some determinants of social and environmental disclosures in New Zealand companies. Accounting, Auditing and Accountability Journal, 9(1), pp. 77-108.

Hamid, S., Craig, R. and Clarke, F. (1993). Religion: a confounding cultural element in the international harmonization of accounting? Abacus, 29(2), pp. 131-48.

Haniffa, R. and Cooke, T. (2002). Culture, corporate governance and disclosure in Malaysian corporations. Abacus, 38(3), pp. 317-349.

Hughes, S., Anderson, A. and Golden, S. (2001). Corporate environmental disclosures: Are they useful in determining environmental performance? Journal of Accounting and Public Policy, vol. 20(3), pp. 217-240.

Imran, A., K. Rehman, Yilmaz, A., Nazir, S. and Ali, J. (2010). Effects of corporate social responsibility on consumer retention in cellular industry of Pakistan. African Journal of Business Management, 4(4), pp. 475-485.

Jahamani, Y. (2003). Green accounting in developing countries: The case of U.A.E and Jordan. Managerial Finance, MCB UP Ltd, 29(8), pp. 37-45. ISSN: 0307-4358. DOI: http://dx.doi.org/10.1108/03074350310768418

Judd, CM, Smith, ER and Kidder, A. (1991. Research Methods in Social Relations, Rinehart and Winston, Fort Worth.

Larbsh, M. (2010). An Evaluation of Corporate Governance Practice in Libya: Stakeholders' Perspectives. Unpublished PhD Thesis, Nottingham Trent University.

Lewis, S. (2001). Measuring corporate reputation, corporate communications: An International Journal. Emerald, vol. 6, Iss: 1, pp.31-35. DOI. http://dx.doi.org/10.1108/13563280110381198. ISSN: 1356-3289.

Manakkalathil, J. and Rudolf, E. (1995). Corporate social responsibility in a globalizing market. SAM Advanced Management Journal, 47, pp. 29-32.

Mangos, N. and Lewis, N. (1995). A Socio-economic paradigm for analysing managers' accounting choice behaviour. Accounting, Auditing and Accountability Journal, 8(1), pp. 38 - 62.

Margolis, J. and Walsh, J. (2003). Misery loves companies: rethinking social initiatives by business. Administrative Science Quarterly, 48(2), pp. 268-305. 
Mashat, A. (2005). Corporate Social Responsibility Disclosure and Accountability (the Case of Libya). Manchester, Manchester Metropoltan University.

Mashat, A., Ritchie, B., Lovatt, C. and Pratten, J. (2005). The Social Role of Accounting: Views and Perceptions of the Accounting, Community in Libya Towards Corporate Social Responsibility and Accountability. Manchester Metropolitan University, UK.

Mateos, ES (2005). Libya's return to the international scene. Taylor \& Francis Online. Mediterranean Politics, vol. 10, no. 3, pp. 439-45. DOI: 10.1080/13629390500289680

Mathews, M. (1993a). Socially Responsible Accounting. Chapman and Hall London.

Mathews, M. (1997b). Towenty-five years of social and environmental accounting research: Is there a silver jubilee to celebrate? Accounting, Auditing \& Accountability Journal, 10(4), pp. 481 - 531.

McWilliams, A. and Siegel, D. (2000). Corporate social responsibility and financial performance: correlation or misspecification? Strategic Management Journal, 21(5), pp. 603-609.

Muthuri, J. Moon, J. and Idemudia, U. (2012). Corporate innovation and sustainable community development in developing countries. Sage Journals. Business \& Society, 51(3), pp. 355-81.From http://bas.sagepub.com/content/early/2012/06/04/0007650312446441.

Ng, L. (1985). Social Responsibility Disclosures of Selected New Zealand Companies for 1981, 1982 and 1983. Occasional Paper.

Oppewal, H., Alexander, A. and Sullivan, P. (2006). Consumer perceptions of corporate social responsibility in town shopping centers and their influence on shopping evaluations. Journal of Retailing and Consumer Services, vol. 13, pp. 261-274.

O'Rourke, D. (2004). Opportunities and Obstacles for Corporate Social Responsibility Reporting in Developing Countries. The World Bank Group oe Corporate Social Responsibility Practice Mar, 27, (3), pp. 39-40.

Patten, D. (1992). Intra-industry environmental disclosures in response to the Alaskan oil spill: a note on legitimacy theory. Accounting, Organizations and Society, 17, (5), pp. 471-475.

Pratten, JD and Mashat, A. (2009). Corporate social disclosure in Libya. Social Responsibility Journal, 5(3), pp. 31127.

Radebauh, H. and Gray, J. (2002).International accounting and multinational enterprises. New York: John Wiley \& Sons Inc.

Romlah, J., Takiah, M. and Nordin, M. (2002). An investigation on environmental disclosures: evidence from selected industries in Malaysia. International Journal of Business and Society, 3(2), pp. 55-68.

S\&P/EGX ESG Index, "Egyptian Institute of Directors, Standard and Poor's, \& Crisil" (2010). Retrived on July 2014. From http://www.egx.com.eg/english/homepage.aspx.

Tilt, CA (1994). The influence of external pressure groups on corporate social disclosure some empirical evidence. Accounting, Auditing \& Accountability Journal, vol. 7( 4), pp. 47-72.

Tsang, E. (1998). A longitudinal study of corporate social reporting in Singapore, the case of the banking; food and hotel industries. Accounting, Auditing and Accountability Journal, 11(5), pp. 624-635.

Unerman, J. (2000). Reflections on quantification in corporate social reporting content analysis. Accounting, Auditing and Accountability Journal, 13(5), pp. 667-680 second issues.

Van der, S., Adhikari, A. and Tondkar, R. (2005). Exploring differences in social disclosures internationally: a stakeholder perspective. Journal of Accounting and Public Policy, 24(2), pp. 123-51.

Walker, R 1985, Doing Research: A Handbook for Teachers. Methuen, London.

Wallace, J. and Wilkinson, B. (2004). Doing Business with Libya. London: Kogan Page Ltd, pp. 7-16.

Williams, M. (1999). Voluntary environmental and social accounting disclosure practices in the Asia-pacific region: an international empirical test of political economy theory. The International Journal of Accounting, 34(2), pp. 209-238.

Zeghal, D. and Ahmed, S. (1990). Comparison of social responsibility information disclosure media used by Canadian firms. Accounting, Auditing \& Accountability Journal, 3(1), 38-53.

Zahra, S. and Stanton, W. (1988). The implications of board of directors' composition on corporate strategy and performance. International Journal of Management, (5)2, 229 - 236. 